\title{
The application of recreational fishing survey data for ecological research, a case study from Western Port,
}

Australia

\section{G. P. JENKINS}

School of BioSciences, University of Melbourne, Parkville \& School of Life and Environmental Sciences, Deakin University, Queenscliff, Victoria, Australia

D. BALL

Unaffiliated marine scientist, Beaumaris, Victoria, Australia

\section{R. A. COLEMAN}

Applied Research, Melbourne Water, Docklands, Victoria, Australia

\section{S. CONRON}

Victorian Fisheries Authority, Queenscliff, Victoria, Australia

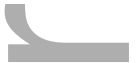

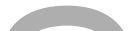

Correspondence: Gregory P. Jenkins, School of BioSciences, University of Melbourne, P.O. Box 114, Queenscliff, VIC 3225, Australia (e-mail: gjenkins@unimelb.edu.au)

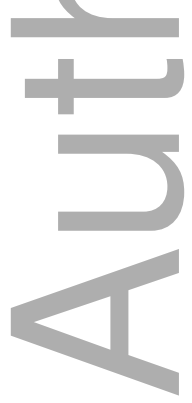

This is the author manuscript accepted for publication and has undergone full peer review but has not been through the copyediting, typesetting, pagination and proofreading process, which may lead to differences between this version and the Version of Record. Please cite this article as doi: 10.1111/FME.12418

This article is protected by copyright. All rights reserved 


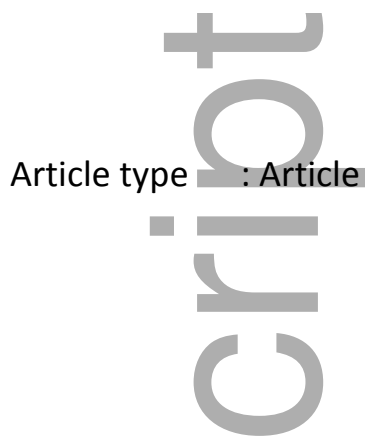

\title{
Application of recreational fishing survey data for ecological research, a case study from Western Port, Australia
}

\begin{abstract}
There is a world-wide need for information on the ecology and habitat dependencies of important fish species. Recreational fishing surveys represent a potential source of data to increase our knowledge of fish distribution and habitat relationships. Here a case study is provided on two key recreational species, King George Whiting Sillaginodes punctatus (Cuvier) and Snapper Chrysophrys auratus (Forster). The data came from a recreational fishing survey where 10,978 interviews were conducted from 1998 to 2013 in Western Port, Victoria, Australia. Spatial mapping of catch rate in relation to depth and habitat showed that S. punctatus distribution was related to seagrass cover while C. auratus distribution was related to deeper reef habitat. Juveniles of both species were more abundant in the southeastern section of the bay, where water quality is affected by catchment inputs. Overall, the study showed that the inclusion of spatial and habitat information in the design of recreational fishing surveys can significantly increase understanding of the ecology of key species.
\end{abstract}

KEY WORDS: creel survey, recreational fishing, habitat, seagrass, depth, distribution, Western Port 


\section{Introduction}

Understanding the ecology and habitat preferences of fish is a key requirement for the sustainable exploitation of fish populations. This is particularly the case for coastal fish populations where environmental conditions and habitat may have a major influence on key population processes, such as recruitment, growth and mortality (Beck et al. 2001; Blandon \& Zu Ermgassen 2014; Morrongiello et al. 2014; Seitz et al. 2014; Jackson et al. 2015).

For species harvested by recreational fishing, survey techniques are commonly used to assess important information for management, such as species composition, catch rate and fish length data (Pollock et al. 1994; Hartill et al. 2012; Wise et al. 2012). However, these surveys also present an opportunity to gain information on the distribution, ecology and habitat preference of recreationally exploited species. For example, information on capture and bathymetric depth from creel surveys has been used to determine temperature preferences of co-occurring fish species (Stewart \& Bowlby 2009).

Western Port, a $680 \mathrm{~km}^{2}$ coastal embayment in south-eastern Australia, is the second largest marine recreational fishery in the State of Victoria. Recreational fishing is mainly boat-based, with only a small amount of shore-based angling. There is limited commercial fishing with all commercial netting phased out in 2009. Western Port is also an important biodiversity region that has been listed as a RAMSAR wetland of international significance and contains three of Victoria's 13 marine national parks (Keough et al. 2011). Western Port supports large areas of habitat, particularly seagrasses, supporting a rich and diverse fish community (Edgar \& Shaw 1995; Jenkins et al. 2015). However, seagrass in Western Port, and Zostera in particular, has been subject to large losses, most markedly in the mid-1970s (Shepherd et al. 1989; Walker 2011). Expansion of the city of greater Melbourne over the past few decades has led to significant population growth in the Western Port catchment, potentially leading to pressure on the environment through increased inputs of toxicants, nutrients and sediments (Keough et al. 2011).

The two most highly targeted recreational fishing species in Western Port are the King George whiting, Sillaginodes punctatus (Cuvier), and snapper, Pagrus auratus (Forster). The minimum legal length for both species is $27 \mathrm{~cm}$ total length. Whiting spawn offshore over winter, and post-larvae then enter Western Port at 3-5 months age and 15-20 mm length 
(Jenkins et al. 2000). After remaining in Western Port in the juvenile phase, sub-adult whiting leave for coastal waters at approximately 4 years of age (Hamer et al. 2004). Most of the snapper in Western Port are likely to have migrated in, as the primary spawning area for snapper in central and western Victoria is nearby Port Phillip Bay (Hamer et al. 2005; Hamer et al. 2011). Migrants into Western Port can range from 1-year old juveniles to adults (Hamer et al. 2005)

This paper reports on a recreational fishing access point survey in Western Port that collected spatial, ecological and habitat data in addition to catch related information. A broad range of species were reported in the surveys, including both targeted and non-targeted species. A case study is provided on two highly targeted recreational species, King George whiting Sillaginodes punctatus and snapper Chrysophrys auratus, for which the most comprehensive information was available, and illustrate the value of including ecological and habitat variables in recreational fishing surveys. The aim was to use recreational fishing survey data to increase our knowledge of the distribution and habitat relationships of key fishery species.

\section{Materials and methods}

\section{Study area}

Western Port has been subdivided into segments based on physical characteristics (Marsden et al. 1979): the Lower North Arm, Upper North Arm, Corinella Segment, Rhyll Segment and Western Entrance Segment (Error! Reference source not found.). Western Port has a large area of intertidal mudflats ( 1/3 of area) dissected by dendritic channels (depth to $30 \mathrm{~m}$ ) with strong tidal currents (Fig. 1). The tidal range of 2-3 m means that a large volume of water is exchanged between the bay and the offshore waters with each tidal cycle. Most of the freshwater input is in the north and north-east of the bay (Fig. 1), and entrainment of sediments from the catchment leads to increased suspended sediments in this area (Wallbrink et al. 2003; Lee 2011; Wilkinson et al. 2016). The dominant biogenic habitat in Western Port is seagrass; the major species are Zostera muelleri on the intertidal flats, Zostera nigricaulis in lower intertidal and shallow sub-tidal areas, and Amphibolis antarctica in the oceanic Western Entrance Segment (Walker 2011; Coleman et al. 2018). The most recent seagrass mapping for the entire Western Port (Fig. 1) was in 1999 (Blake \& Ball 2001). At this point, seagrass cover was increasing after a major loss in the 1970s and 1980s (Blake \& Ball 2001). Seagrass cover is likely to have fluctuated over the period of the recreational fishing survey; 
however, the basic distribution of seagrass in Western Port tends to be relatively consistent (Blake \& Ball 2001).

\section{Recreational fishing survey}

The data analysed came from the Victorian Fisheries Recreational Survey (Ryan \& Conron 2019) conducted in Western Port from November 1998 to 2013. Interviews were conducted with boat-based fishers returning from fishing trips on weekends from approximately October - November to April - June each year. A total of 10,978 interviews was conducted at 13 ramps spread around the perimeter of the bay. Information provided from approximately 25 questions included number of fishers, hours fished, species caught and released, and fish length. The information also included the area fished based on the catch cells previously developed for commercial log book recording (See map in supporting information S1). Information on the bottom depth of the fishing location was included from 2007/2008 and information on the bottom habitat type was included from 2010/2011. Options given for bottom habitat type were three natural habitats: reef, sand or mud, seagrass; and, two artificial habitats, artificial reef or "other". A sixth habitat option was "unknown". No location or depth information was recorded if the fisher was unsure of the answer.

\section{Data analysis}

To analyse the spatial information contained in the Recreational Fishing Survey data, the catch rate was determined for each species on each fishing trip (number of fish caught/released/ angler hr effort). The catch rate data were allocated to the area fished based on the catch cells. Where more than one catch cell was fished on a trip the calculated catch rate was applied to each cell equally. The catch rate was chosen as the appropriate variable because it represents an index of abundance. Catch cells were only included in the analysis if more there were more than 10 interviews represented in the data. For C. auratus and S. punctatus the data were filtered to include only trips where these species were targeted, and both kept and released fish were analysed. The majority of releases of these species are because fish are under the minimum legal length. As the length at maturity of both species is above $27 \mathrm{~cm}$ (Jenkins et al. 2012; Kemp et al. 2012), released fish can be considered a proxy for pre-recruits. ARCMAP GIS software (Version 10.2, Environmental Systems Research Institute Inc.) was used to determine the area of seagrass and mean subtidal depth in each catch cell. Bathymetry polygon data available for the bay had depth contour intervals of 2,5 
$10,15,20$ and $30 \mathrm{~m}$. The total area of each depth contour interval in a cell was calculated using GIS. A mid-point depth value was assigned to the areas of each contour interval (e.g. 25-m depth range assigned depth of $3.5 \mathrm{~m}$ ) to calculate a mean water depth of each catch cell. The depth and habitat of fishing were plotted in terms of the number of trips a species was caught (or released) at each depth and in each habitat. Depth data were restricted to interviews where only one location (catch cell) was fished. Spearman's rank correlation was used to analyse correlation between spatial distributions of catch rates and the percentage of seagrass cover and mean depth of cells. The non-parametric Kolmogorov-Smirnov test was used to determine if the frequency distribution of successful fishing trips in relation to depth was significantly different between kept and released fish. The outcomes of the analysis of the catch cells are described in relation to the corresponding overlapping Western Port segments (Marsden et al. 1979) (Fig. 1). The table in supporting information S2 shows the number of interviews contributing to the data analysis by catch cell, depth and habitat.

\section{Results \\ King George whiting}

Spatial distribution of catch rates The catch rate of kept King George whiting was highest north-west of French Island, in the Upper North Arm near Tooradin and in the Rhyll Segment (Fig. 2A). The catch rate of released King George whiting was highest in the Rhyll and Corinella segments and was also relatively high in the Upper North Arm from Hastings to Tooradin (Fig. 2B).

Areas of higher catch rates of kept whiting (Fig. 2A) broadly corresponded with areas of the bay with greatest seagrass cover (Fig. 1). There was a significant positive correlation between catch rates of kept whiting and percentage seagrass cover in cells $\left(\mathrm{R}_{\mathrm{s}}=0.39, \mathrm{n}=21, \mathrm{P}<0.05\right)$ but the distribution of catch rates of released whiting and percentage seagrass cover was not correlated $\left(\mathrm{R}_{\mathrm{s}}=0.01, \mathrm{n}=21, \mathrm{P}>0.05\right)$.

Areas of higher catch rates of kept whiting were not correlated with the mean depth of catch cells $\left(R_{s}=-0.20, n=21, P>0.05\right)$. By contrast, there was a strong negative correlation between catch rates of released whiting and the mean depth of catch cells $\left(R_{s}=-0.57, n=21, P<0.005\right)$, indicating that catch rates were higher in cells with shallower mean depth. 
Successful fishing trips in relation to depth Fishing trips where kept whiting were caught were mainly in shallow depths of 2 to $10 \mathrm{~m}$ with a small proportion of catches in depths of 10 to $30 \mathrm{~m}$ (Fig. 3A). The distribution of depths of capture was shallower for released whiting with a high proportion of released fish captured in depths of 3 to $6 \mathrm{~m}$ and a very low proportion caught in depths greater than $10 \mathrm{~m}$ (Figure 3B). The peak in successful trips was at $6 \mathrm{~m}$ depth for kept whiting (Fig. 3A) compared with only $3 \mathrm{~m}$ depth for released whiting (Fig. 3B). The frequency distribution of successful fishing trips in relation to depth was significantly different between kept and released whiting (KS test, $\mathrm{D}=0.132, \mathrm{P}=0.007$ ).

Successful fishing trips in relation to habitat Most fishing trips where kept whiting were caught were on mixed sand and seagrass habitat, with trips fishing on sand and seagrass habitat also commonly producing whiting (Fig. 3C). A lower proportion of successful fishing trips was also recorded for reef and mixed reef and sand habitats (Fig. 3C). The pattern was similar for released whiting with mixed sand and seagrass the most important habitat, but in this case, reef associated habitats were of low importance (Fig. 3D).

\section{Snapper}

Spatial distribution of catch rates The catch rate of snapper was highest in the Western Entrance Segment and in the Lower North Arm (Fig. 4A), corresponding to the deepest areas of Western Port (Fig. 1). Moderate catch rates were also recorded in the Rhyll Segment (Fig. 4A). Areas of higher catch rates of released snapper also included the Western Entrance Segment and Lower North Arm but were relatively higher in the Rhyll Segment and Eastern Entrance (Fig. 4B).

Areas of higher catch rates of kept snapper were strongly correlated with the mean depth of catch cells $\left(\mathrm{R}_{\mathrm{s}}=0.75, \mathrm{n}=18, \mathrm{P}<0.001\right)$. By contrast, there was no significant correlation between catch rates of released snapper and the mean depth of catch cells $\left(R_{\mathrm{s}}=0.36, n=18\right.$, $\mathrm{P}>0.05)$. No significant correlation was found between percentage seagrass cover in cells and catch rates of snapper that were kept $\left(R_{s}=-0.11, n=18, P>0.05\right)$ or released $\left(R_{s}=-0.32, n=18\right.$, $\mathrm{P}>0.05)$

Successful fishing trips in relation to depth Fishing trips where kept snapper were caught were in a broad range of depths with the highest proportion between 7 and $18 \mathrm{~m}$ (Fig. 5A). A small proportion of fish were caught at greater depths ranging down to $35 \mathrm{~m}$ (Fig. 5A). Released snapper were caught over a similar depth range but the highest proportion of 
catches was slightly shallower in the range of 3 to $15 \mathrm{~m}$ (Fig. 5B). The peak in successful trips was at $10 \mathrm{~m}$ depth for kept snapper (Fig. 5A) compared with $7 \mathrm{~m}$ depth for released snapper (Fig. 5B). The frequency distribution of successful fishing trips in relation to depth was significantly different between kept and released snapper (KS test, D $=0.179, \mathrm{P}<$ $0.001)$.

Successful fishing trips in relation to habitat Most fishing trips where kept snapper were caught were on reef habitat, with trips fishing on mixed sand and seagrass habitat also producing some snapper (Fig. 5C). Very few fishing trips resulted in kept snapper captures where fishing was on seagrass habitat (Fig. 5C). The pattern was similar for released snapper although mixed reef and sand habitat, sand habitat, and mixed sand and seagrass habitat were relatively more important than for kept snapper (Fig. 5D).

\section{Discussion}

The value of recreational survey data in understanding fish ecology and habitat relationships

Recreational fishing surveys are primarily focussed on stock assessment and management, including information on species composition, catch rates and fish length (Pollock et al. 1994; Hartill et al. 2012; Wise et al. 2012). There is an opportunity to also obtain information on fish habitat, ecology and biodiversity through these surveys, but this opportunity has only had limited uptake to date. A few studies have previously used recreational surveys to determine harvest rates in different habitats and broad locations (Parnell et al. 2010; Ochwada- Doyle et al. 2014). Some studies have also used recreational surveys to obtain information on harvest rates and depth (Stewart \& Bowlby 2009; Parnell et al. 2010). The relatively few examples of this broader approach to surveys in the literature may reflect the surveys being mainly considered a stock assessment and management tool, and the potential to obtain ecology and habitat information is yet largely unrealised.

Recreational surveys have the potential drawback of unreliability in reporting by fishers, but these errors are likely to be offset by the very large sample sizes that can be obtained. Some of the potential error inherent in asking fishers to provide exact location details was reduced in this study by the use of broader catch reporting cells. This spatial information could then be incorporated into GIS and compared with habitat spatial distribution. The inclusion of information on habitat in the surveys was novel and proved very useful when matched with the location information in the analysis. Recreational surveys also have the potential to 
provide long-term monitoring information on fish-habitat relationships with potential matching with fishery-independent information from habitat monitoring.

\section{Case study species}

Whiting were associated with areas of higher seagrass cover in Western Port and were mainly taken in areas of seagrass and sand, and in particular mixed (patchy) seagrass/sand habitat. Whiting post-larvae initially settle in shallow seagrass habitat over spring (Jenkins \& May 1994; Jenkins \& Wheatley 1998; Jenkins et al. 2000). As the juveniles grow, however, they tend to occur in mud/sand habitat near the edge of seagrass beds (Jenkins \& Wheatley 1998; Smith et al. 2011; Jenkins et al. 2012). This habitat shift, based on previous research in Western Port, may relate to a shift from a diet dominated by seagrass epifauna to one dominated by infaunal polychaetes (Robertson 1977). The productivity of the sand/mud habitat near the edge of seagrass is likely to be increased by enrichment from seagrass detritus (Jenkins et al. 2012). Whiting were primarily taken in shallow sub-tidal depths down to $10 \mathrm{~m}$ and mostly in depths down to $6 \mathrm{~m}$. This depth range is consistent with the depth distribution of seagrass in the bay (Blake et al. 2012).

'Released' whiting (i.e. those smaller than the legal minimum length) would have been mostly 2 year olds in the $20-27 \mathrm{~cm}$ range. The GIS spatial analysis indicated that the distribution of these whiting was more related to shallow depths than the distribution of seagrass, and this was supported by the shallower distribution of released whiting indicated by successful fishing trips. Although data are less reliable than for kept whiting due to a smaller sample size and lack of targeting, this result is consistent with research in Port Phillip Bay showing that small juvenile whiting are mainly found in shallow water and gradually move into deeper water as they grow (Jenkins et al. 2012). Released whiting were relatively more abundant in the Rhyll segment that is characterised by a large shallow basin $(<5 \mathrm{~m}$ depth) that has soft sediments and mixed seagrass and algal habitats (Blake et al. 2012).

\section{Snapper}

The spatial distribution of kept snapper catch rates was highest in the Western Entrance segment and the southern part of the Lower North Arm, corresponding with the deepest areas of Western Port. There was no strong association with seagrass distribution, which is also the case in Port Phillip where snapper above Legal Minimum Length (LML) mostly occur on deeper soft sediments and reefs (Coutin et al. 2003; Kemp et al. 2012). 
The contention that the distribution of larger snapper is linked to the deeper areas of Western Port is supported by data showing fishing was most successful in depths of 7 to $18 \mathrm{~m}$ (and down to $35 \mathrm{~m}$ ), indicating that fishing is often occurring in deeper channels. In particular, successful snapper fishing trips occurred when fishing deeper reef habitat, although trips fishing on mixed sand/seagrass habitat also resulted in some snapper catches. Deeper channels with strong currents in Western Port have significant areas of biogenic reefs formed by bryozoans, sponges and other sedentary invertebrates (Blake et al. 2012). These reefs are likely to form important habitat for larger snapper. Released (mainly undersized) snapper tended to be caught in shallower water and a greater variety of habitats, probably reflecting their higher abundance in the relatively shallow Rhyll Segment.

\section{Management Implications}

The inclusion of spatial, ecological and habitat information in recreational fishing surveys can increase the data available to advocate for activities, such as habitat protection, rehabilitation and restoration, potentially leading to more productive fisheries. Inclusion of this information may also provide information on habitat changes over time in the case of ongoing surveys. If the spatial distribution of recreational fishing effort changes over time this might indicate an issue with habitat change or loss.

The dependence of whiting on seagrass, combined with their high abundances in the Upper North Arm and Rhyll Segments of Western Port where water quality is strongly influenced by catchment inputs in the north-east of the bay (Wallbrink et al. 2003; Lee 2011; Wilkinson et al. 2016), means that this species is vulnerable to changes in catchment activities that may alter pollutant loads, particularly sediments. Seagrass loss in the early 1970s was mainly in the Upper North Arm, and the Corinella and Rhyll Segments, and was thought to be related to sediments from the catchment settling on seagrass leaves and blocking light (Shepherd et al. 1989).

Catch rates of released, predominately smaller juvenile whiting and snapper, were relatively higher in the Rhyll Segment than catch rates of older fish. The Rhyll basin is a broad subtidal sedimentary plain with habitats such as seagrass, macroalgae and sedentary invertebrate isolates (Blake et al. 2012; Jenkins et al. 2013). The Rhyll Segment is also strongly influenced by water quality and sedimentation entering the north-east of the bay from the catchment, so catchment management to maintain and improve water quality entering the bay 
in the context of continuous urban growth and climate change is likely to be critical to sustaining this area as a habitat for juveniles of key species.

\section{Conclusions}

The recreational fishing survey data proved a valuable tool for understanding the distribution and habitat relationships of two key fishery species in Western Port. The study showed that the inclusion of ecological information in the design of recreational fishing surveys can significantly enhance the overall value of these surveys by increasing our understanding of habitat and ecology of key species. Further value was added by including spatial information from surveys in GIS that allowed comparison with habitat mapping layers. Overall, the study provided new information on the spatial distribution and habitat use of important fish populations in Western Port that will inform management of the marine environment in relation to catchment inputs, coastal development, recreational fishing and marine protected areas.

\section{References}

Beck M.W., Heck K.L., Able K.W., Childers D.L., Eggleston D.B. et al. (2001) The identification, conservation, and management of estuarine and marine nurseries for fish and invertebrates. Bioscience 51, 633-641.

Blake S. \& Ball D. (2001) Victorian Marine Habitat Database: Seagrass Mapping of Western Port. . Marine and Freshwater Resources Institute Report, Queenscliff No. 29. $36 \mathrm{pp}$.

Blake S., Ball D., Coots A. \& Smith T. (2012) Marine video survey of Western Port. Fisheries Victoria Technical Report, Department of Primary Industries, Queenscliff, Victoria, Australia No. 176. 53 pp.

Blandon A. \& Zu Ermgassen P.S.E. (2014) Quantitative estimate of commercial fish enhancement by seagrass habitat in southern Australia. Estuarine, Coastal and Shelf Science 141, 1-8.

Coleman R., Bathgate R. \& Keough M.J.K. (eds.) (2018) Understanding the Western Port environment: a summary of research findings from the Western Port Environment Research Program 2011-2017 and priorities for future research, Melbourne Water Corporation: Victoria. 
Coutin P.C., Cashmore S. \& Sivakumuran K.P. (2003) Assessment of the snapper fishery in Victoria. Final report to Fisheries Research and Development Corporation, Australia. No. 97/127. 210 pp.

Edgar G.J. \& Shaw C. (1995) The production and trophic ecology of shallow-water fish assemblages in southern Australia I. Species richness, size-structure and production of fishes in Western Port, Victoria. Journal of Experimental Marine Biology and Ecology 194, 53-81.

Hamer P.A., Acevedo S., Jenkins G.P. \& Newman A. (2011) Connectivity of a large embayment and coastal fishery: spawning aggregations in one bay source local and broad-scale fishery replenishment. Journal of Fish Biology 78, 1090-1109.

Hamer P.A.,Jenkins G.P. \& Gillanders B.M. (2005) Chemical tags in otoliths indicate the importance of local and distant settlement areas to populations of a temperate sparid, Pagrus auratus. Canadian Journal of Fisheries and Aquatic Sciences 62, 623-630.

Hamer P.A., Jenkins G.P. \& Sivakumaran K.P. (2004) Identifying the spawning locations of King George whiting in Victorian waters: a recreational fishing based study. Fisheries Victoria Research Report Series No. 21.

Hartill B.W., Cryer M., Lyle J.M., Rees E.B., Ryan K.L. et al. (2012) Scale- and contextdependent selection of recreational harvest estimation methods: the Australasian experience. North American Journal of Fisheries Management 32, 109-123.

Jackson E.L., Rees S.E., Wilding C. \& Attrill M.J. (2015) Use of a seagrass residency index to apportion commercial fishery landing values and recreation fisheries expenditure to seagrass habitat service. Conservation Biology 29, 899-909.

Jenkins G.P., Black K.P. \& Hamer P.A. (2000) Determination of spawning areas and larval advection pathways for King George whiting in southeastern Australia using otolith microstructure and hydrodynamic modelling. I. Victoria. Marine Ecology Progress Series 199, 231-242.

Jenkins G.P., Hutchinson N., Hamer P.A. \& Kemp J. (2012) Fisheries Adaptation to Climate Change - Marine Biophysical Assessment of King George whiting. Fisheries Victoria Research Report Series No. 57. 41 pp.

Jenkins G.P., Kenner T. \& Brown A. (2013) Determining the specificity of fish-habitat relationships in Western Port. Centre for Aquatic Pollution Identification and Management, University of Melbourne, Technical Report No. 26. 64 pp. 
Jenkins G.P., Kenner T., Brown A. \& Coleman R. (2015) Fish assemblages in locations with alternative structured habitats in an eelgrass, Zostera, dominated bay: Biodiversity value and potential for refuge. Estuarine, Coastal and Shelf Science 161, 25-37.

Jenkins G.P. \& May H.M.A. (1994) Variation in settlement and larval duration of King George whiting, Sillaginodes punctata (Sillaginidae), in Swan Bay, Victoria, Australia. Bulletin of Marine Science 54, 281-296.

Jenkins G.P. \& Wheatley M.J. (1998) The influence of habitat structure on nearshore fish assemblages in a southern Australian embayment: comparison of shallow seagrass, reef algal, and unvegetated habitats, with emphasis on their importance to recruitment. Journal of Experimental marine Biology and Ecology 221, 147-172.

Kemp J., Conron S., Hamer P., Bruce T., Bridge N. et al. (2012) Victorian Snapper Stock Assessment 2011. Fisheries Victoria Assessment Report Series No. 64.

Keough M.J., Bathgate R., Lee R., Jenkins G., Walker D. et al. (2011) Understanding the Western Port Environment. A summary of current knowledge and priorities for future research. A report for Melbourne Water, Department of Sustainability and Environment and the Port Phillip and Westernport CMA. Melbourne Water Corporation.

Lee R. (2011) Chapter 4 - Physical and Chemical Setting. Understanding the Western Port Environment. A summary of current knowledge and priorities for future research. Melbourne: Melbourne Water.

Marsden M.A.H., Mallett C.W. \& Donaldson A.K. (1979) Geological and physical setting, sediments and environments, Western Port, Victoria. Marine Geology 30, 11-46.

Morrongiello J.R., Walsh C.T., Gray C.A., Stocks J.R. \& Crook D.A. (2014) Environmental change drives long-term recruitment and growth variation in an estuarine fish. Global Change Biology 20, 1844-1860.

Ochwada- Doyle F.A., Mcleod J., Barrett G., Clarke G. \& Gray C.A. (2014) Spatial patterns of recreational exploitation in eastern Australian ROFAs: implications for zonal management. Fisheries Management and Ecology 21, 383-397.

Parnell P.E., Dayton P.K., Fisher R.A., Loarie C.C. \& Darrow R.D. (2010) Spatial patterns of fishing effort off San Diego: implications for zonal management and ecosystem function. Ecological Applications 20, 2203-2222.

Pollock K.H., Jones C.M. \& Brown T.L. (1994) Angler survey methods and their applications in fisheries management: American Fisheries Society, Maryland, USA. 
Robertson A.I. (1977) Ecology of juvenile King George whiting Sillaginodes punctatus (Cuvier and Valenciennes) (Pisces: Perciformes) in Western Port, Victoria. Australian Journal of Marine and Freshwater Research 28, 35-43.

Ryan K.L. \& Conron S.C. (2019) Comparing indicators of recreational fishing in Port Phillip Bay, Australia, from 2008 to 2011 with variability from a background period (200307). Marine and Freshwater Research 70, 1345-1357.

Seitz R.D., Wennhage H., Bergström U., Lipcius R.N. \& Ysebaert T. (2014) Ecological value of coastal habitats for commercially and ecologically important species. ICES Journal of Marine Science 71, 648-665.

Shepherd S.A., McComb A.J., Bulthius D.A., Neverauskas V., Steffensen D.A. et al. (1989) Decline of seagrasses. In: A.W.D. Larkum, A.J. McComb \& S.A. Shepherd (eds.) Biology of Seagrasses. Amsterdam: Elsevier.

Smith T.M., Hindell J.S., Jenkins G.P., Connolly R.M. \& Keough M.J. (2011) Edge effects in patchy seagrass landscapes: The role of predation in determining fish distribution. Journal of Experimental Marine Biology and Ecology 399, 8-16.

Stewart T.J. \& Bowlby J.N. (2009) Chinook Salmon and Rainbow Trout Catch and Temperature Distributions in Lake Ontario. Journal of Great Lakes Research 35, 232238.

Walker D.I. (2011) Chapter 10 - Seagrasses. Understanding the Western Port Environment. A summary of current knowledge and priorities for future research. Melbourne: Melbourne Water.

Wallbrink P.J., Hancock G.J., Olley J.M., Hughes A., Prosser I.P. et al. (2003) The Western Port Sediment Study. CSIRO Consultancy Report.

Wilkinson S.N., Anstee J.M., Joehnk K.D., Karim F., Lorenz Z. et al. (2016) Western Port sediment supply, seagrass interactions and remote sensing. Report to Melbourne Water. CSIRO, Australia.

Wise B.S., Telfer C.F., Lai E.K.M., Hall N.G. \& Jackson G. (2012) Long-term monitoring of boat-based recreational fishing in Shark Bay, Western Australia: providing scientific advice for sustainable management in a World Heritage Area. Marine and Freshwater Research 63, 1129-1141. 


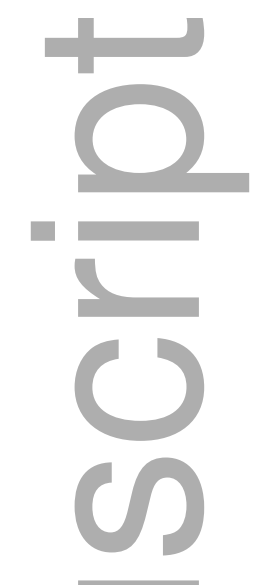

Figure Captions

Figure 1: Map of Western Port including Segments of Western Port based on physical characteristics (Marsden et al. 1979), distribution of seagrass in Western Port mapped in 1999 (Blake \& Ball 2001), and bathymetric contours. Insets: Location of Western Port on the Victorian coast and location of the State of Victoria in Australia.

Figure 2: Spatial distribution of the catch rate of King George whiting, (A) kept fish, (B) released fish.

Figure 3: Number of trips where King George whiting were caught in relation to bottom depth at the fishing location, A) Kept fish, B) Released fish; and, habitat at the fishing location C) Kept fish, D) Released fish.

Figure 4: Spatial distribution of the catch rate of snapper, (A) kept fish, (B) released fish.

Figure 5: Number of trips where snapper were caught in relation to depth at the fishing location, A) Kept fish, B) Released fish; and, habitat at the fishing location, C) Kept fish, D) Released fish. 

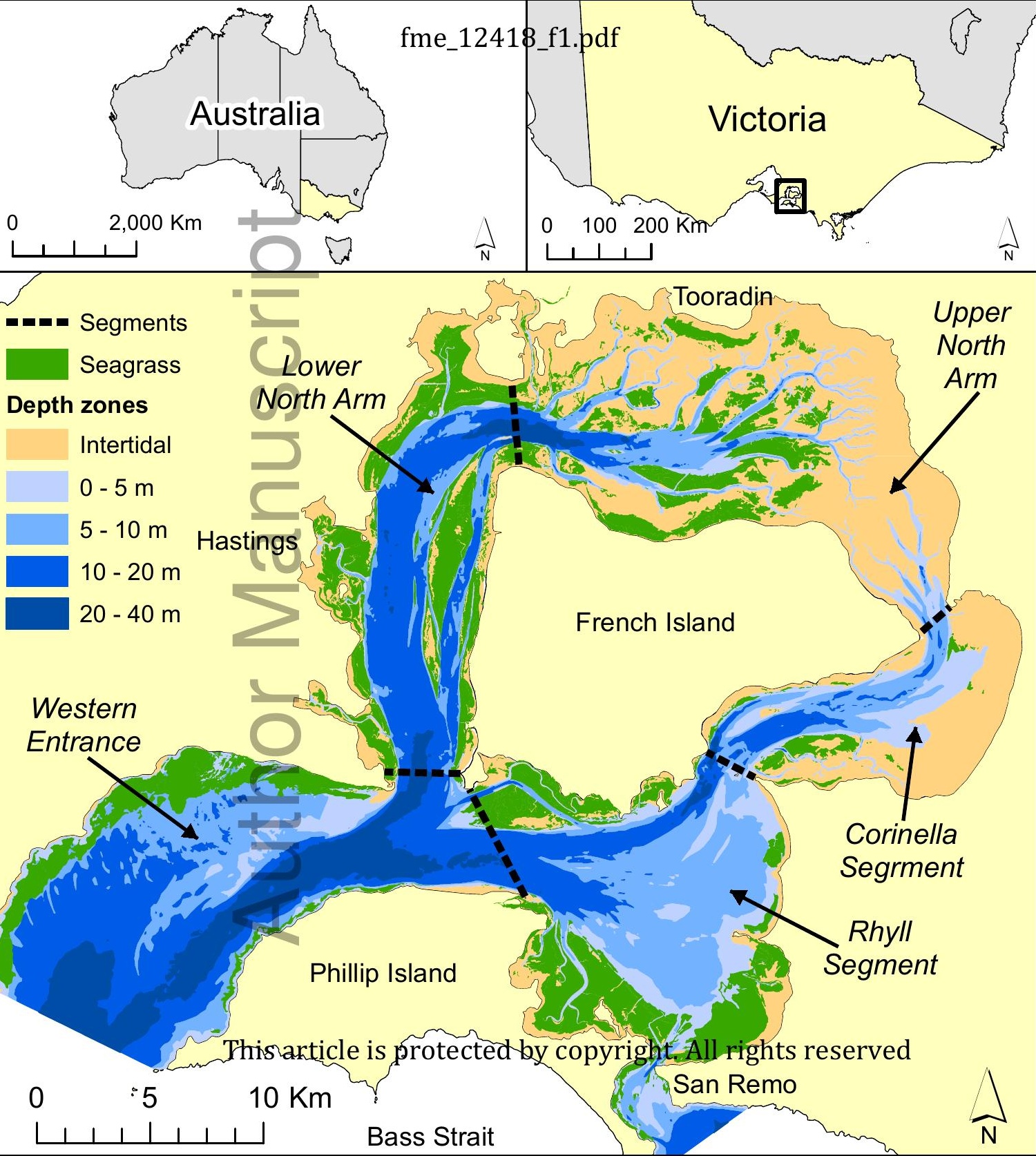

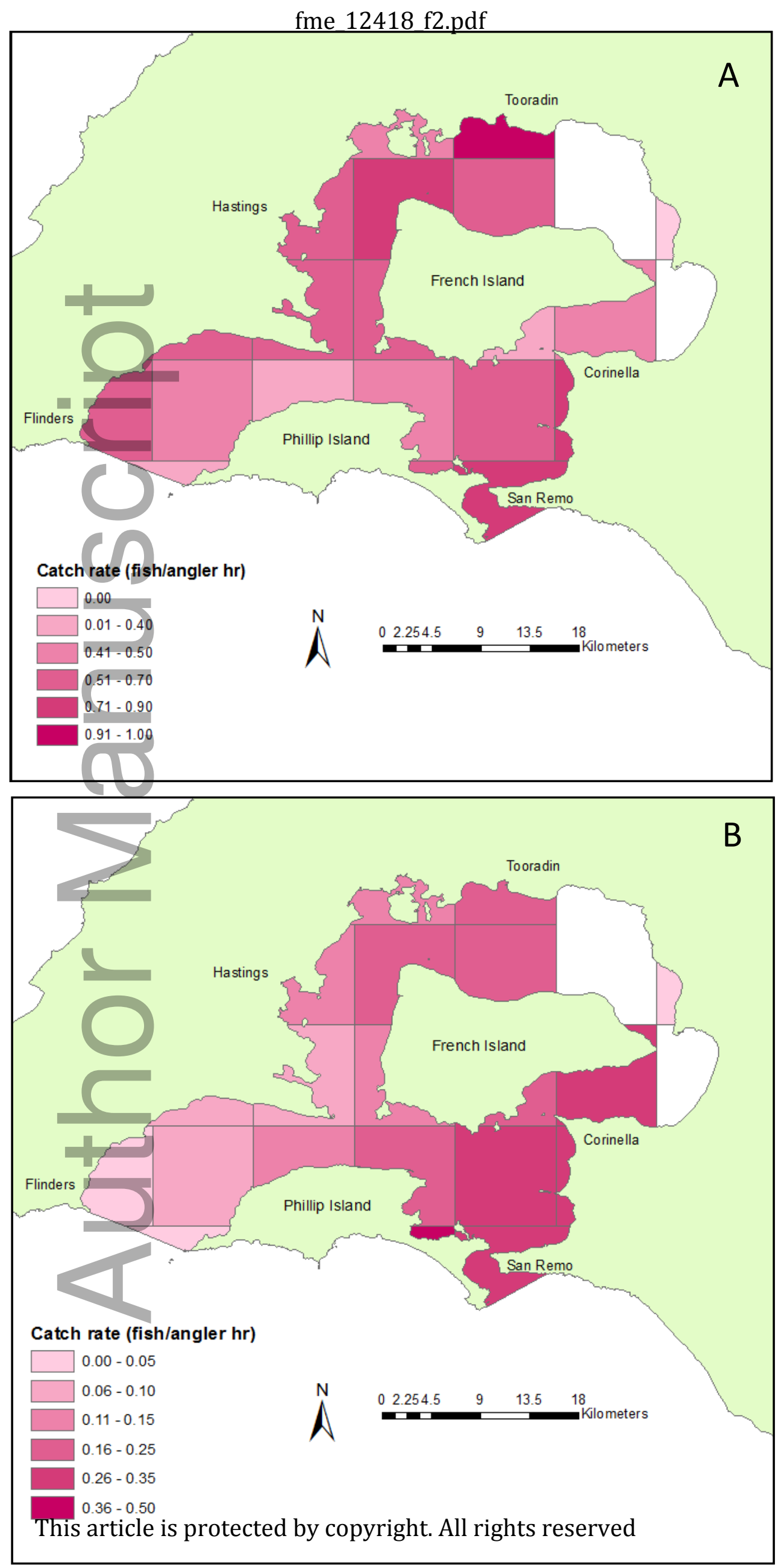


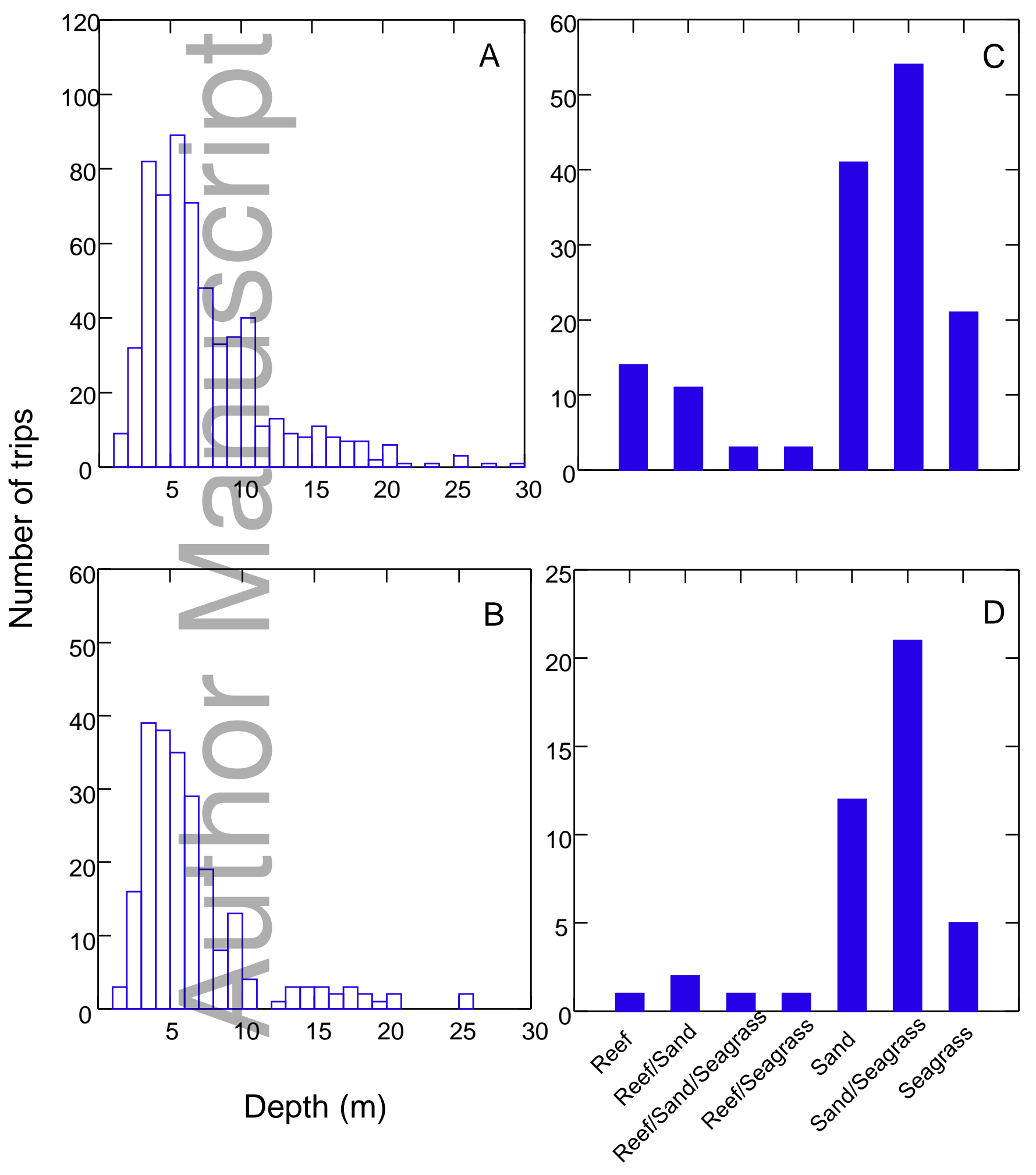

Habitat 

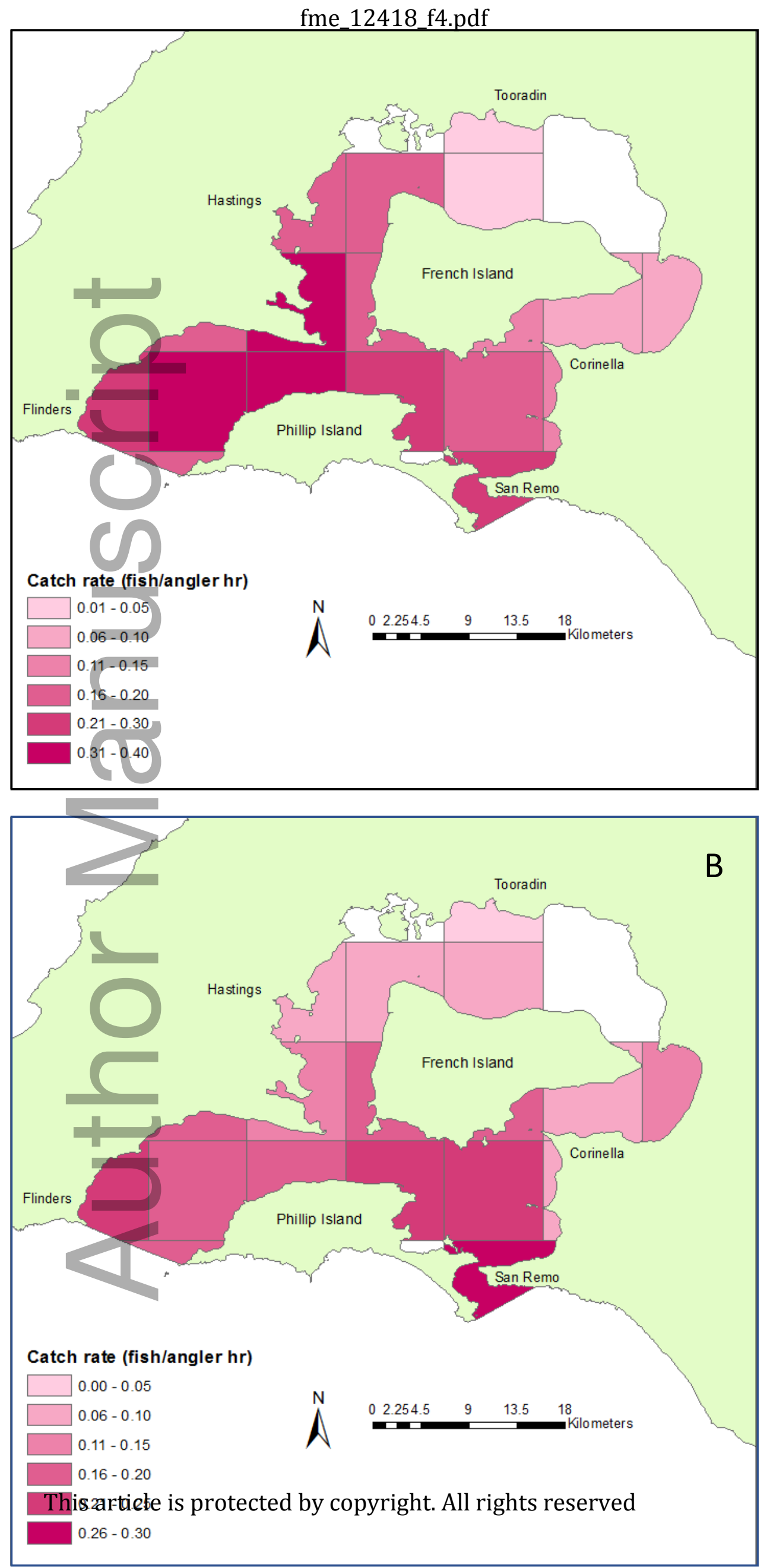

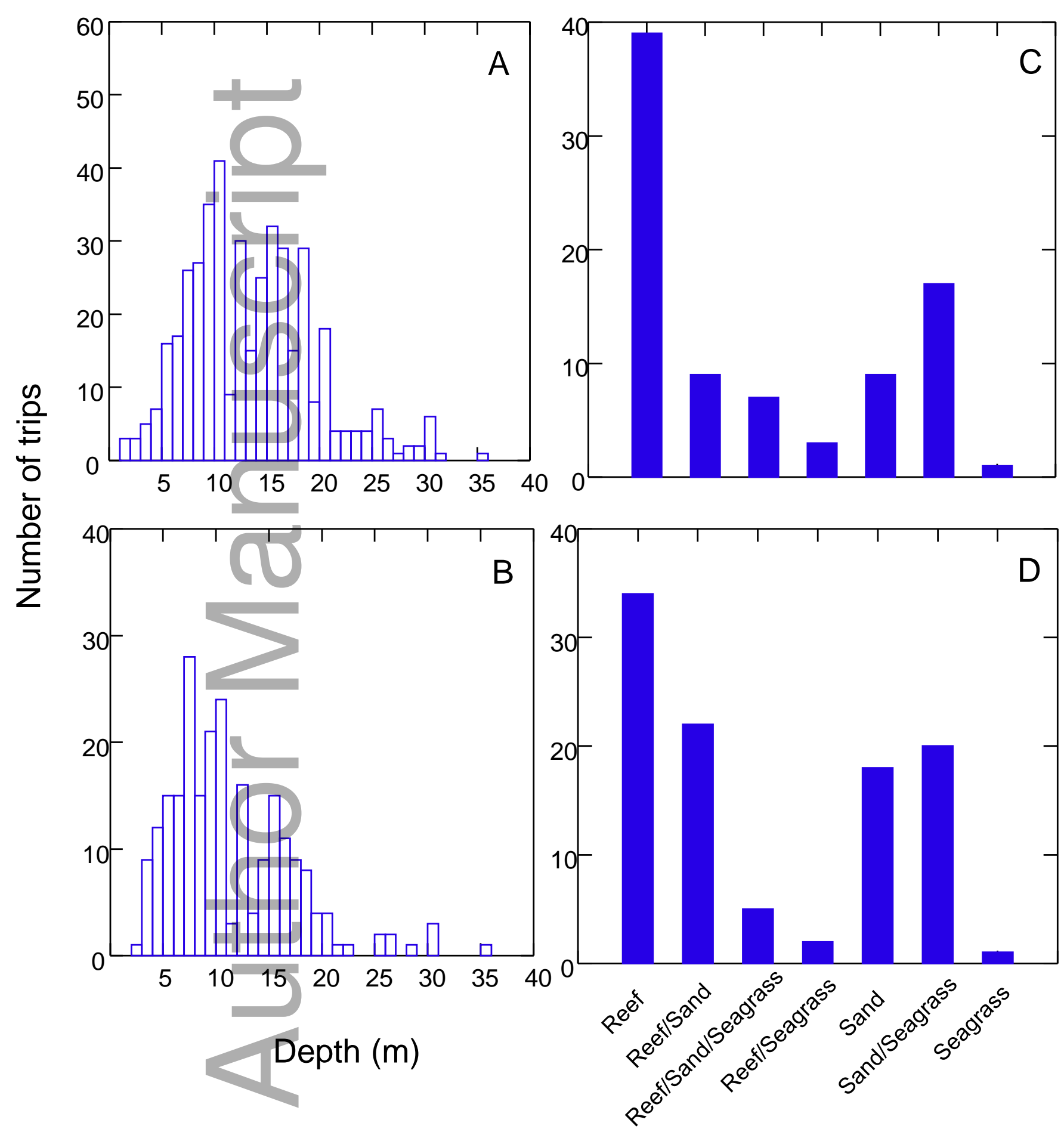

Habitat 


\section{University Library}

\section{- M M I N E R VA A gateway to Melbourne's research publications}

Minerva Access is the Institutional Repository of The University of Melbourne

Author/s:

Jenkins, GP;Ball, D;Coleman, RA;Conron, S

Title:

The application of recreational fishing survey data for ecological research, a case study from Western Port, Australia

Date:

2020-03-03

Citation:

Jenkins, G. P., Ball, D., Coleman, R. A. \& Conron, S. (2020). The application of recreational fishing survey data for ecological research, a case study from Western Port, Australia.

FISHERIES MANAGEMENT AND ECOLOGY, 27 (4), pp.357-366. https://doi.org/10.1111/ fme.12418.

Persistent Link:

http://hdl.handle.net/11343/275504 